Article

\title{
The Role of Consumers in the Achievement of Corporate Sustainability through the Reduction of Unfair Commercial Practices
}

\author{
Borko Mihajlović \\ Faculty of Law, University of Kragujevac, Kragujevac 34000, Serbia; bmihajlovic@jura.kg.ac.rs; \\ Tel.: +381-34306531
}

Received: 22 October 2019; Accepted: 14 January 2020; Published: 31 January 2020

\begin{abstract}
The subject of this article is a determination of the potential of the prohibition of unfair commercial practice, as an institution of consumer law, established to strengthen consumers' protection, to contribute to the achievement of corporate sustainability. The main objective of the paper is the identification of situations in which certain companies' actions may at the same time be considered as unsustainable and socially irresponsible behavior, as well as unfair commercial practice. There are three such characteristic situations that were the subject of thorough analysis in the paper: (1) company's constantly invoking to the concepts of corporate sustainability and corporate social responsibility (CSR) in its marketing activities, which is essentially incorrect because the company in practice breaches some of the basic postulates of these concepts, (2) breach of company's code of conduct which contains the principles of corporate sustainability and CSR, and which the company has undertaken to be bound, (3) conducting many concrete acts which represent unfair commercial practice, and simultaneously have negative impact on the corporate sustainability and CSR. From the analysis of these three situations arises the conclusion that there is a possibility for indirect legal sanctioning of the unsustainable and socially irresponsible behavior of companies through the application of the consumer law rules on the prohibition of unfair commercial practice.
\end{abstract}

Keywords: unfair commercial practices; corporate sustainability; corporate social responsibility; CSR claims; sustainability claims; corporate sustainability codes of conduct

\section{Introduction}

Achievement and strengthening, as well as, reaching higher levels of corporate sustainability through the permanent and continuous process are necessary for contemporary society. The corporate sustainability is not relevant only for the companies, but also for the states and societies where they function and operate, as well as for the entire environment. There are different ways and mechanisms for the achievement and strengthening corporate sustainability, which entail the initiative and participation of different actors. Some authors think that key role in reaching the corporate sustainability should belong to the companies [1] (p. 377), some would argue that market forces may solve the problem, as they solved many other problems, and the others, however, claim that this issue is too important for our planet so to freely indulge it to the private sector. Therefore, they emphasize the need for inclusion of the state, i.e., for the state's intervention, which primarily may contribute to corporate sustainability with its legal regulation [2]. Some authors consider the role of civil society, the public, and the media, as the key one, specifically that the external stakeholders' pressure should be more vigorous and frequent [3] (pp. 99-100). It seems that none of these social actors have the potential to independently influence the achievement and strengthening of corporate sustainability. The real and strong corporate sustainability may be reached only through the common action of all these mentioned actors, i.e., through the synergy of the business, the market, the state, and the civil society. 
Among the most important actors, which should contribute to the achievement and strengthening of corporate sustainability, the potential of consumers has not been sufficiently recognized, used, and researched so far. This potential may be significant, as consumers are the largest group of stakeholders of many companies. The notion of the consumer in this paper is used in the way as it is defined in the EU consumer law, i.e., as a natural person who is acting in the market for purposes which are outside his trade, business, craft or profession [4]. The significance of the consumers for the achievement and strengthening of corporate sustainability emanates also from the fact that they present "the common element" of all different actors which contribute to the corporate sustainability (business, market, state, civil society), that is, they are, in some way, related to each of these actors. Consumers are an integral part of the civil society, they are the subject of interest of the state, which strives to protect them with the special legal regulation, and they are as well, perhaps, the most important market force which impacts the operation of companies. The role and significance of consumers in the achievement and strengthening of corporate sustainability relate most commonly to the concepts of ethical consumerism and sustainable consumption [5]. The main objective of these concepts is the promotion of making consumers' economic decisions not only on the basis of the quality and price of the products and services, and concrete consumer's needs but also on the basis of economic and social characteristics of products and services. These concepts encourage consumers' decision making based on the fact of whether companies acted socially responsible during the production and distribution of products and services [6]. There are also some different views, established on the premise that current consumption behaviors harm the achievement of corporate sustainability due to the fact that the values of consumers' society promote massive consumption, which is one of the main reasons for environmental and the social crisis faced by our planet [7] (p. 47). However, consumption itself does not have to be negative, quite the contrary, if it is "sustainable", it positively impacts sustainable development, and therefore the focus still should stay on finding the mechanisms for incitement of sustainable consumption.

The main subject of this paper deals with the role and significance of the consumers for the achievement and strengthening corporate sustainability through the application of the rules of consumer law, specifically in this case through the application of the rules which regulate one of the most important institutions of consumer law-unfair commercial practice. We will analyze the role and significance of the consumers in the application of the rules on unfair commercial practice through the situations in which the companies' behavior on the market, which is not in accordance with the concept of corporate sustainability at the same time presents the unfair commercial practice as well. We will conduct this analysis, aiming to indicate the real possibility of indirect influence, i.e., indirect sanctioning of the companies which do not act under the concept of corporate sustainability through the application of consumer law rules.

The idea of sanctioning unsustainable companies through the application of the rules on the prohibition of unfair commercial practices is not entirely new. It has been subject to partial analysis in the previous literature, primarily from the aspect of breaches of codes of conduct, which contain companies' commitments about corporate sustainability and corporate social responsibility goals. This article aims to build further knowledge on the foundations which have been already set. The main objective of this article is a comprehensive analysis of all provisions on unfair commercial practices in EU consumer law and assessing the possibility of implementing these provisions in the sanctioning of unsustainable companies' behavior.

Before we move to the analysis of the main subject of this paper, we will deal with the issue of the definition of the concept of corporate sustainability, which is the question of initial importance for this paper. It is also important to determine the relationship between the concepts of corporate sustainability and corporate social responsibility (hereinafter: CSR) since these two concepts have very similar meanings and goals. 


\section{The Concept of Corporate Sustainability}

The concept of corporate sustainability is one among many concepts, which purpose is the promotion and achievement of broader societal goals through the operation of companies, as the basic and the most important vehicles for conducting business activities. Besides this concept, some of the concepts, which in different, but mainly similar ways, deal with the role of business in the contemporary society or with the necessary interconnection between business and society, are CSR, responsible business conduct [8], corporate social performance [9], corporate sustainable development, corporate social accountability, corporate citizenship [10], environmental management, etc. All these concepts are the result of a decades-long debate on the role and contribution of the business to the broader social community, which has been most often conducted through the well-known dispute between the adherents of the shareholder theory and stakeholder theory on the purpose of the company [11-13]. The concepts on the role of business in society arise from the stakeholder approach of the company's purpose. The same as the debate on the company's purpose has not been ended thus far, leaving many issues disputable and still unsolved [14,15], almost all the above-mentioned concepts remain to a certain extent insufficiently clearly determined, which is noticeable in the academic discussion as well as in the business practice. The ambiguities and dilemmas about the definitions of the concepts on the role of business in a society largely emanate from their proximity, interconnection, and impossibility to draw a clear borderline between them.

Similar to the definitions of the above-mentioned concepts, which are various, the concept of corporate sustainability is also susceptible to different interpretations. In the beginning, it may be safely stated that the corporate sustainability emanates from the broader concept of sustainable development, and also that these two concepts are inextricably connected. Many authors take this fact as a decisive one when they define corporate sustainability. Some authors consider that the relationship between corporate sustainability and sustainable development is so strong that there is no difference between the two concepts [16]. They simply equalize sustainable development and corporate sustainability [16]. The largest number of the authors notice the difference between these concepts, but they emphasize that three basic components on which these concepts are founded are identical: environmental, social, and economic. According to Sjåfjell, corporate sustainability is "when business in aggregate create value in a manner that is: (a) environmentally sustainable in the sense that it ensures the long-term stability and resilience of the ecosystems that support human life, (b) socially sustainable in the sense that it facilitates the respect and promotion of human rights, and (c) economically sustainable in the sense that it satisfies the economic needs necessary for stable and resilient societies [1] (p. 378)." An interesting example of the definition of corporate sustainability, which expresses its undisputable relationship with the concept of sustainable development, is the one according to which this concept entails satisfaction of the expectations of the present stakeholders without jeopardizing the interests of future stakeholders [17] (p. 256). From this definition, we also conclude that the concept of corporate sustainability refers to the sustainable development of the company, as an individual business entity, and which consequentially makes a contribution to the sustainable development of the entire society and the planet. For that reason, it is incorrect to equalize the concepts of corporate sustainability and sustainable development. Besides definitions that are more or less founded on the concept of sustainable development, some authors define corporate sustainability in a slightly different way. Van Marrewijk argues that there should not be a general, unique notion of corporate sustainability, but that the meaning of this notion should be adjusted to the facts of a concrete case, depending on the needs and motivations of each particular company [3] (p. 102). Hahn and Scheermesser take a very similar stand formed after their empirical research on the meaning of the concept of corporate sustainability for the individual German companies [18] (pp. 160-161). Schaltegger et al. emphasize the market component of the corporate sustainability in the definition of this concept, i.e., the business case for the application of the concept of corporate sustainability, which is usually considered in the modern literature as the most important motivation of companies for acting in accordance with this concept [19] (pp. 219-220). 
It has been already stated that corporate sustainability has similarities with many other concepts that deal with the role and contribution of the business to modern society. Most often it is associated with the concept of CSR, whereby these two concepts are usually considered synonyms. The CSR concept arose before corporate sustainability. According to some authors, it appeared in the 1950s, while others emphasize that this concept became subject of wider interest in the 1970s and 1980s [17]. Generally accepted definition of CSR does not exist. The main reason for the non-existence of one and unique definition is the fact that the CSR concept encompasses broad specter of business and social aspects, as well as a large number of actors, whose interests and perceptions are frequently contradicted. Here we will present a few definitions of CSR, which we consider the most relevant and important for the subject of this paper. An unavoidable definition of CSR is the one founded on Carroll's pyramid of social responsibility, which encompasses four components: economic, legal, ethical, and philanthropic, that is discretionary responsibility [20]. As the basic and the most important component of the social responsibility of companies Carroll sees economic responsibility, which he considers the foundation for achieving its ethical and discretionary responsibilities towards society [20]. McBarnett also thinks that profit remains the basic purpose of the companies, while CSR answers the question of what are the socially responsible ways of making a profit [21] (p. 1). In other words, the goal of CSR is finding a way to reconcile making a profit, on the one hand, and social and environmental responsibilities to the society, on the other hand [21] (p. 1). McBarnett emphasizes that special companies' policies on models for reconciliation of competing interests may be found in the business principles and codes of conduct of companies [21] (p. 1). Some authors assert that the key component of CSR is the relationship of the company with its stakeholders. Accordingly, they define CSR as a strategic approach to the business based on stakeholders' needs [3]. The objective of CSR, according to these views, is gaining a higher quality of life for all stakeholders, along with the inevitable maintenance of the company's profitability [3]. CSR is also defined as the process for integration of social, environmental, ethical, human rights, and consumer concerns in everyday business operation and strategy of the companies, aiming to achieve as closely as possible cooperation with the stakeholders [8]. CSR has two main objectives, which we may determine positively and negatively: maximization of value creation for shareholders, other stakeholders, and entire society (positive determination of CSR objective), and identification, prevention, and mitigation of possible harmful impacts on the social community (negative determination of CSR objective) [8].

One of the contentious issues regarding the CSR concept is the issue of whether this concept is based on voluntary business activities of companies or it presents a direct or indirect obligation of companies. The European Commission primarily in its first Green Paper on CSR explicitly defined CSR as a voluntary activity [22], while in its new definition from 2011 the Commission consciously omitted the word which indicated to the voluntariness of the concept [8]. The issue of voluntariness or legal obligingness remains opened and unsettled. Here we should mention a traditional distinction between two sorts of CSR-implicit and explicit $[23,24]$. The implicit CSR is characteristic for the countries of the continental-European legal tradition, and among those countries, some of them, like Germany, have always been inclined to the stakeholder approach of the company's purpose. Implicit CSR is related to the countries and societies in which acting under the CSR principles is already embedded in the legal norms and case law [25] (pp. 404-405). For this reason, CSR as a concept in these countries has not had greater significance since the socially responsible behavior is implied, and it is the obligation of the companies to a great extent. Explicit CSR is a consequence of the flexible legal regulation of the companies' behavior on the market, and it exists as a result of an internal and external need of companies to act socially responsible [25] (pp. 404-405). Division of the concept of CSR on implicit and explicit tells us about the significance of differentiation between behavior which is at the same time socially irresponsible (and thus unsustainable) and illegal, and behavior which is socially irresponsible (and thus unsustainable) and legal. From the legal aspect, the last type of socially irresponsible and unsustainable behavior is particularly important because it could be elusive from the perspective of legal regulation and legal sanctions. 
Another frequently analyzed question with regard to the CSR concept, which is also relevant for the subject of this paper, concerns motivation, i.e., the reasons for the adoption of CSR principles and practices in the operation of the companies. The theory adduces two main reasons, that is, moral and business reasons (moral case and business case for CSR). It is widely accepted that in the contemporary economy the business case dominates as the trigger for the socially responsible behavior of many companies [26] (pp. 44-45). Simply speaking, it means that companies act in accordance with the CSR concept because they believe that this behavior "pays off", that it is not an expenditure but investment, that it is positive for the image and reputation of the company, their relationship with consumers and employees, as well as for their entire position in the social community where they operate [27] (p. 217). Although at first glance it seems that the business case for CSR brings to the ideal solutions, which are favorable for the society, the environment, and the business, we may legitimately raise the issue of the existence and sustainability of this "ideal" situation. Empirical research on the positive impact of the socially responsible behavior of companies on its business results are very limited and insufficient [28-30], and even if the research unequivocally shows the existence of the relationship between social responsibility and a profit, it would have led us again to the wrong way and to the conclusion that the company should behave socially responsible only when it is profitable (that is not always the case). For that reason, the business case as the only motive for the adoption of CSR principles has been subject to critique. The moral case for CSR is founded on the belief that the achievement of CSR itself is an important goal of the company. The moral reasons for the implementation of CSR principles establish the socially responsible behavior of companies on the fundamental principles of morality [26] (pp. 46-47).

After the analysis of some definitions and specifics of the concepts of corporate sustainability and CSR, we turn to the determination of the relationship between these two concepts. Both concepts are indisputably the way for reaching sustainable development as the ultimate goal [31], although it seems that certain differences between them do exist. It has been asserted that activities focused on the achievement of corporate sustainability mainly concern environmental issues, while the CSR activities primarily deal with social issues (human rights, relationships with stakeholders) [17] (p. 101). However, the concepts of corporate sustainability and CSR are certainly very close and inextricably linked. In this paper, we will consider the corporate sustainability as a broader notion, which encompasses CSR, as a narrower notion. The definition of corporate sustainability is determined by its relationship with the CSR. The notion of corporate sustainability has two components: internal and external. The internal component of the notion presents the basis of the concept of corporate sustainability, and it concerns the sustainability of the company itself, its long-term and stable business operation, which may be reached for the most part through the maintenance of good relationships with all stakeholders (through the CSR activities directed towards stakeholders). The external component concerns the contribution of the company to the achievement of global sustainable development, and particularly its contribution to the overall environmental, social, and economic sustainability. The external component is dependent on the internal because only the company which is sustainable and stable in the business sense may contribute to sustainability at the global level. CSR, in our opinion, is a narrower notion, which is primarily related to the concrete activities that companies introduce in their business policies, and implement aiming to reach its internal and external sustainability. The choice of concrete activities depends on the motives and business objectives of each particular company, i.e., its owners and management, business and social environment, legal regulation, and many other factors. It is quite clear though that these activities largely regard the relationship of the company with different external stakeholders, among which the most important are the social community and natural environment within which the company operates, employees, and consumers.

The corporate sustainability is not a unique concept which has the identical meaning and importance in every concrete case, for every particular company, in every concrete state and part of the world. The importance of this concept changes depending on the level of development of one society and state, the level of developed social sense of the citizens as consumers, on the stage of 
development of the companies which implement the concept, financial results of the company and many other factors. Some authors drew very similar conclusions, arguing that there are different levels of corporate sustainability, which move from very weak to very strong sustainability [3] (p. 102).

In the end, we should stress that, according to the presented views about the relationship between corporate sustainability and CSR, CSR is the fundamental way for concretization and realization of corporate sustainability. This fact is of utmost importance for the main subject of this paper, i.e., for the application of the rules on the unfair commercial practice on the situations in which companies do not follow the principles and rules of the CSR concept, that is the principles and rules of the concept of corporate sustainability, which we may consider too as the rules and principles of the good business practice.

\section{The Legal Regime of the Unfair Commercial Practices in the EU Law}

The prohibition of the unfair commercial practice is one of the legal institutions which contribute to the establishment of the conscious and honest behavior of all market participants [32]. This institution became particularly relevant after the adoption of the EU Unfair Commercial Practices Directive (hereinafter: UCPD) [4]. The main objective of UCPD is the proper functioning of the internal market and achievement of a high level of consumer protection by approximating the legal rules of the EU Member States on unfair commercial practices harming consumers' economic interests (UCPD, Art. 1). Detailed analysis of the unfair commercial practice is not the subject of this paper. In this part of the paper, we will provide only a short overview of the basic notions and concepts relevant to the legal regime of unfair commercial practice. These concepts and notions are as following: regulatory approach to the unfair commercial practices in the EU law, the notion of commercial practices, general requirements for existence of unfair commercial practice, misleading commercial practices, aggressive commercial practices, the blacklist of unfair commercial practices, as well as the fundamental mechanisms for the realization of the consumers' right to be protected from the unfair commercial practices. Certain elements of these notions and concepts relevant to this paper will be analyzed in detail in the following part of the paper.

The EU legislator has accepted the so-called three-tiered cascading approach in the regulation of unfair commercial practices [33] (p. 97). This means that the general requirements for the existence of unfair commercial practice are primarily determined (general clause). Misleading and aggressive commercial practice, as manifestations of commercial practice which are considered particularly unfair, are regulated afterward ("small general clauses") [34]. In the end, there is a blacklist of misleading and aggressive commercial practices, which prescribes behaviors considered unfair in all circumstances [33] (p. 97). The application of the three-tiered approach in the practice, i.e., in the procedure of determination of the existence of the unfair commercial practice, entails the check by the competent judicial or administrative authority whether the commercial practice subject to examination is prescribed at the blacklist as absolutely prohibited. If the answer to this question is positive, it will not be necessary to analyze the requirements from the general clause. If the answer is negative, the organ competent to make a decision will examine the fulfillment of conditions for the existence of the misleading or aggressive commercial practice. In case that these conditions are not fulfilled, the general clause, which has the role of the safety net, will be analyzed [35] (pp. 12-13).

UCPD adopts a very broad notion of commercial practice. Commercial practice means any act, omission, course of conduct or representation, commercial communication including advertising and marketing, by a trader, directly connected with the promotion, sale or supply of a product to consumers (UCPD, Art. 2(d)).

The general clause of the unfair commercial practice contains two basic requirements which have to be cumulatively met for qualification a commercial practice as unfair. The first requirement is that commercial practice is contrary to the requirements of professional diligence [36] (pp. 264-268). Professional diligence means the standard of special skill and care which a trader may reasonably be expected to exercise towards consumers, commensurate with honest market practice and/or the 
general principle of good faith in the trader's field of activity (UCPD, Art. 2(h)) [33] (pp. 98-99). The second requirement is that commercial practice materially distorts or is likely to materially distort the economic behavior with regard to the product of the average consumer whom it reaches or to whom it is addressed, or of the average member of the group when a commercial practice is directed to a particular group of consumers (UCPD, Art. 5(2)). Actual distortion of the consumer's economic behavior is not a necessary condition for qualification trader's behavior as unfair commercial practice. On the contrary, it is sufficient that there is only the possibility of distortion $[33,35]$. The existence of damage is also not necessary for the establishment of unfair commercial practice, which means that the trader may be liable even without any damage as a consequence of his behavior. A trader materially distorts the economic behavior of consumers when he uses a commercial practice to appreciably impair the consumer's ability to make an informed decision, thereby causing the consumer to take a transactional decision that he would not have taken otherwise (UCPD, Art. 2(e)). It is necessary to determine which consumers' decisions are considered as transactional decisions, in order to establish the cases in which a trader materially distorts the economic behavior of consumers. UCPD defines the transactional decision of consumers in a very broad manner. The transactional decision means any decision taken by a consumer concerning whether, how and on what terms to purchase, make payment in whole or in part for, retain or dispose of a product or to exercise a contractual right in relation to the product, whether the consumer decides to act or to refrain from acting (UCPD, Art. 2(k)). This definition encompasses many different decisions made by consumers in a long period, from the moment when the consumer was exposed for the first time to the advertisement of product or service until its final use [35].

A misleading commercial practice is a practice that induces the consumer to take a transactional decision that he would not have taken otherwise. This is also a common characteristic for all forms of misleading commercial practice, which mutually differs in the way of consumer's deception. Using misleading commercial practice by the trader implies preventing consumers through the fraud to make an informed choice established on all elements necessary for making the transactional decision. The misleading commercial practice may be conducted through misleading acts or misleading omissions [37]. Aggressive commercial practice exists when the practice, in its factual context, taking account of all its features and circumstances, by harassment, coercion, including the use of physical force, or undue influence, significantly impairs or is likely to significantly impair the average consumer's freedom of choice or conduct with regard to the product and thereby causes him or is likely to cause him to take a transactional decision that he would not have taken otherwise (UCPD, Art. 8).

UCPD states that the EU Member States shall ensure that adequate and effective means exist to combat unfair commercial practices to achieve the interest of consumers (UCPD, Art. 11(1)). There are two basic models of protection: judicial and administrative. The EU Member States may freely choose one of those two models of protection. This is in accordance with the view that the model of protection is not decisive, but its efficiency. Consumers' protection from unfair commercial practice may be realized in two ways: individually or collectively [32,38].

\section{The Achievement and Strengthening Corporate Sustainability through the Application of Rules on the Prohibition of Unfair Commercial Practices}

Unfair commercial practice as an institution established to protect and empower consumers certainly has not been mainly focused on the achievement and strengthening of corporate sustainability. The creators of the rules on unfair commercial practices did not have as well the intention to make these rules one of the bases for strengthening corporate sustainability when they conceived those rules. The fact that corporate sustainability is not subject to mandatory legal regulation, although discussions about its introduction are still ongoing and becoming ever intensive, imposes the necessity to deliberate on novel legal mechanisms that contribute to corporate sustainability through the application of rules which have been created for pursuing some other goals. In that sense, McBarnett talks about the states which strengthen the CSR (and at the same time corporate sustainability) with indirect regulation, while 
some old and sometimes forgotten rules obtain the new role, and some other primarily private law rules obtain new usage [21]. This tendency has to be contemplated in the context of the stronger pursuit of civil society to use every possible legal mechanism which aims to strengthen the application of the concepts of corporate sustainability and CSR [21]. Prohibition of unfair commercial practices has the potential to attain an indirect impact on the achievement and strengthening of corporate sustainability and CSR through the active role of consumers and consumers' organizations. In this part of the paper, we will try to identify different situations in which the application of the rules on unfair commercial practice may positively influence the achievement and strengthening of corporate sustainability and CSR. We will expose three characteristic situations in which a possibility for attainment of this influence exists: (1) company's constantly invoking the concepts of corporate sustainability and CSR in its marketing activities, which is essentially incorrect because the company in practice breaches some of the basic postulates of these concepts, (2) breach of company's code of conduct which contains the principles of corporate sustainability and CSR, and which the company has undertaken to be bound, (3) conducting many concrete acts which represent unfair commercial practice, and simultaneously have negative impact on the corporate sustainability and CSR since they do not respect one of the main principles on which these principles are embedded-maintenance of good relationships with all stakeholders, and particularly consumers. After the analysis of fulfillment of requirements necessary for establishment of unfair commercial practice in the above-mentioned situations, we will deal with the realization of consumers' rights, and especially with the collective protection, since all the instances of unfair commercial practice followed by legal proceedings brought by consumers' organizations or a large number of individual consumers may have considerable negative impact on the position of the company on the market.

\subsection{Untruthful Invoking of the Companies that They Follow the Principles of Corporate Sustainability and CSR}

The first situation in which there is the possibility of influence of the rules on unfair commercial practice on the achievement and strengthening the corporate sustainability and CSR is the one when the company constantly, and consciously, with the intent to gain advantage in the market competition, emphasizes the fact that it is socially responsible, i.e., that it operates its business following the principles of corporate sustainability and CSR. This situation arises from the U.S case law, and more specifically from the case Kasky vs. Nike [39] (pp. 1170-1175) [40] (p. 707).

There are different ways in which the company may invoke respect for principles of corporate sustainability and CSR. It may do that on its web site, in the brochures, on its business premises, as well as during another, different advertising activities. What is common for all these methods of company's representation is the creation of impression to the consumers that the company whose products and services they intend to purchase or to use, operates a business in a socially responsible manner. In this case, similar to the facts in Kasky vs. Nike, we talk about the situation in which the company's claim about its socially responsible behavior does not have a direct relationship with the products or services which the consumer intends to purchase or use [39] (p. 1170). If it turns out that the company's claim was false, precisely that the company essentially does not respect the principles of corporate sustainability and CSR, we may raise the question of whether the company using this false claim breaches the prohibition of unfair commercial practice to consumers. In the beginning, we should stress that in the present case neither the application of the rules contained in Annex I of UCPD, nor the rules contained in the "small" general clauses (misleading and aggressive commercial practice) are possible. None of 31 situations prescribed in the Annex I correspond to this particular situation. There are also no elements of harassment, coercion, undue influence, which are necessary prerequisites for the establishment of aggressive commercial practice. There might be a dilemma regarding the possibility to apply rules on misleading commercial practice. However, in our opinion, these rules are also most often not applicable, since UCPD explicitly states the elements in relation to which there must be a deception by a company. These elements are determined in a very concrete manner, and they primarily concern the characteristics of the product or service itself, the price, the production, delivery, 
etc. (UCPD, Art. 6(1)). For that reason, it is necessary to examine the possibility of the application of the general clause of unfair commercial practice on the situation which is subject to analysis.

It has been already stated that the general clause contains two requirements that must be cumulatively met. The false company's claim on respect for the principles of corporate sustainability and CSR undoubtedly presents behavior contrary to the requirements of professional diligence. Therefore, the first requirement from the general clause is met. Although the meaning of this standard is not clearly enough determined in the EU consumer law, it unequivocally requires a higher standard of diligence on the market from traders (companies) comparing to the other market actors [35] (pp. 72-73). The satisfaction of the second requirement from the general clause may be disputable, having in mind that it contains several elements whose existence, in this case, must be particularly examined. We distinguish three elements which we consider the most significant for the analyzed situation: (1) direct connection of the practice to the promotion, sale or delivery of the products, (2) the notion of the average consumer, and (3) material distortion of the economic behavior of the consumer.

UCPD certainly adopts a very broad notion of the commercial practice. An important element of this notion is a direct connection of the practice to the promotion, sale or delivery of the products, which may be controversial in this case. However, the possibility of subsuming the analyzed situation under the notion of commercial practice stems from its direct connection to the promotion. Namely, empirical research shows that the business motives and reasons are the main drivers for the socially responsible activities of the companies [27] (pp. 217-218). When we talk about the business reasons and motives, the most prominent place among them belongs to the creation of the positive image and brand of the company towards consumers. For that reason, we think that there is room for accepting the interpretation under which invoking the fact that the company follows the principles of corporate sustainability and CSR presents the practice which is directly connected to the promotion. It is possible to assert the counter-argument based on the wording of UCPD, which requires a direct connection, while in this case, only an indirect connection may exist. Yet, the main intention and rationale of UCPD, which is visible also in the notion of commercial practice, is the protection of the economic interests of consumers from the unfair advertising and marketing in the broadest sense [35] (p. 16). In support of this, we may also point out to the case-law of the European Court of Justice, which accepts a "strikingly" broad notion of commercial practice [41] (p. 482). For all those reasons, it seems that we may draw a conclusion that the company's claim stating respect for the principles of corporate sustainability and CSR presents commercial practice.

The effect of commercial practice must be assessed from the perspective of its influence on the economic behavior of the average consumer. UCPD accepts the definition of the average consumer developed in the ECJ case law, under which the average consumer is the one who is reasonably well-informed and reasonably observant and circumspect, taking into account social, cultural and linguistic factors [35] (p. 24). For our considerations, it is necessary to determine whether and to what extent the fact that the company follows the principles of corporate sustainability and CSR impacts the transactional decisions of the average consumer. Even though the ethical consumerism has become over time stronger and more important, there is no clear empirical research how the fact that the company, whose products and services the consumer intends to purchase or use, respects the principles of corporate sustainability of CSR influences the economic decision of the average consumer. Behavior and expectations of the average consumer differ from country to country, and sometimes even within the same country [33] (p. 100). This uncontentious fact concerns the behavior of consumers in all fields, but it might be especially expressed with respect to the behavior and expectations of the consumers based on CSR claims of the companies. In the Nordic countries, in which the role and sense of the civil society about the importance of sustainable development and the contribution of the companies to its achievement are traditionally at the very high level, we may expect that the average consumer actually considers companies' statements on corporate sustainability and CSR. The picture is, however, entirely different, for instance, in the countries of southeast Europe, in which civil society still does not pay enough attention to sustainable development. Also, in these countries, due to the lower living 
standard, the average consumer is not always in the position to give priority to the environmental and social characteristics of the companies and its products and services compared to the price and quality of these products and services when he makes his transactional decisions. Therefore, the potential for the application of the general clause of unfair commercial practice, considering the different meaning of the standard of the average consumer in developed and less developed countries, is significantly higher in the developed countries.

The last and the most important question regarding the application of the general clause of unfair commercial practice on the analyzed situation concerns the consequences of the company's unfair behavior on the market. Two facts considerably facilitate the fulfillment of the second requirement from the general clause: (1) the non-existence of the condition that material distortion of the economic behavior of consumers has actually occurred, (2) the broad interpretation of the notion of the transactional decision of the consumer. As examples of the transactional decision of the consumers, the Guidance on the application of UCPD asserts the consumer's decision to only enter the shop, to spend more time at the web site than primarily planned, not to switch the provider of the services or the seller, i.e., to remain loyal to his provider or seller [42] (pp. 33-35). In the case we analyze, it means that consumer's decision to spend a little more time at the company's web site, which emphasize that the company is sustainable and socially responsible, presents a transactional decision, as well as a decision to enter the shop only due to the fact that the consumer read the brochure in which the company invokes the principles of corporate sustainability and CSR. The decision to remain loyal to the company, whose products and services the consumer uses only because it represents itself as a sustainable and socially responsible company also presents a transactional decision. It is realistic to expect that the average consumer, especially in the societies where ethical consumerism and sustainable consumption are deeply entrenched, makes the transactional decisions, in the way this concept is construed under UCPD, on the bases of the claims about corporate sustainability or CSR.

In the end, there seems to be a real possibility of the application of the general clause of unfair commercial practice on the company's incorrect claims about respect for the principles of corporate sustainability and CSR. Whether this possibility will become an actual responsibility of the company depends on the initiative of the consumers and consumers' organizations, as well as on the readiness of the courts to give broad interpretation to the notions relevant for the application of the general clause of unfair commercial practice and to make adequate decisions able to force companies to actually operate their business in a sustainable and socially responsible manner. The content of the notion "average consumer" seems to be the most relevant. At least at this moment, it is hard to say that in the less developed countries the average consumer sufficiently considers the environmental and social parameters of the company's business operation while making economic decisions. From this fact emanates once again the significance of the consumers' information and education about the sustainable consumption, since the raising of the consumers' awareness simultaneously changes the content of the standard of the "average consumer". The changed content and meaning of this legal standard facilitate the application of the general clause of unfair commercial practice on situations in which the companies in different ways explicitly claim that they respect the principles of corporate sustainability and CSR.

\subsection{Breach of the Codes of Conduct which Contain the Principles of Corporate Sustainability and CSR}

The principles of corporate sustainability and CSR are usually embedded in the special companies' codes of conduct. The company may make its own CSR code of conduct or corporate sustainability code of conduct, or it can sign the code of conduct made by an international organization, chamber of commerce, or any other organization that promotes the achievement of the principles of corporate sustainability and CSR. The codes of conduct are often published at the company's web site or made available to the public in some other way, and companies commonly refer to these codes in its advertising campaigns or marketing activities [43]. Legally contemplated, codes, as a set of principles and norms of desirable, conscious, and honest behavior are not binding, i.e., subject to legal 
sanctions [44]. Codes brought by the institution (organization, chamber of commerce) have a certain level of obligingness because the institution controls their application, and sanctions non-compliance with the code by imposing the measures that have internal character. However, breach of code of conduct may be also legally sanctioned with the application of the rules on misleading commercial practice, as a form of unfair commercial practice [45] (pp. 269-270). Misleading commercial practice exists if the trader, in its factual context, taking account of all its features and circumstances, causes or is likely to cause the average consumer to take a transactional decision that he would not have taken otherwise, by the breach of the commitments contained in code of conduct he signed, if the commitment is not aspirational but is firm and is capable of being verified, and the trader indicates in a commercial practice that he is bound by the code (UCPD, Art. 6(2)). UCPD contains as well the definition of the codes of conduct, according to which the code represents an agreement or set of rules not imposed by law, regulation or administrative provision of a Member State which defines the behavior of traders who undertake to be bound by the code in relation to one or more particular commercial practices or business sectors (UCPD, Art. 2(f)). From the stated definitions arise that four conditions should be met for the legal sanctioning of non-compliance with the commitments contained in the code. Those conditions concern: (1) "the code-maker", the nature and content of the code (meeting the requirements from the definition of the code of conduct), (2) the nature of the commitments undertaken, which were breached by the trader (company), (3) trader's indication in the commercial practice that he is bound by the code, (4) economic effect to the average consumer.

The definition of the code of conduct does not directly determine who may have the role of "code-maker", specifically whether the definition of the code from UCPD encompasses only the codes adopted by the organization (institution) or the codes brought by the individual companies as well. For that reason, this issue has been subject to debates in the legal literature. The perplexity is caused by the definition of the code of conduct which speaks about the behavior of traders (in plural). This fact brought some authors to the conclusion that UCPD applies only to the institutional codes [41] (p. 494). This interpretation would harm the possibility of application of the analyzed form of misleading commercial practice on the strengthening the corporate sustainability since the principles of corporate sustainability and CSR are often embedded in the individual codes of conduct of companies. On the other hand, Beckers made an argument, which we consider correct, that the application of UCPD should not be narrowed only to the institutional codes of conduct. She established her argument on the reasons for adoption of the provision on non-compliance with the commitments contained in the code as a form of misleading commercial practice (concretization of the general clause), context in which this provision was brought (promotion of self-regulation in the EU), and literal interpretation (the code which adopts one company may regulate behavior of the number of traders if the company operates as a part of the corporate group or supply or distribution chain) [41] (pp. 494-495). In support of this view speaks the definition of the code owner which UCPD accepts, according to which the code owner may be the individual trader as well (UCPD, Art. 2(g)). Here we may add that exclusion of the individual codes from the definition of the codes of conduct would undoubtedly harm the economic interests of the consumers which may be jeopardized by the institutional and individual codes as well. Determination of the nature and content of the codes which implement the principles of corporate sustainability and CSR should not pose particular practical problems. In respect of nature, it presents a set of rules which is not part of the state regulation but presents self-regulation. With regard to the content, there may be an issue of whether provisions related to the rules and principles of corporate sustainability and CSR may be considered as one or more particular commercial practices. We believe that the answer to this question is positive because the contemporary approach to corporate sustainability and CSR entails integrating sustainability in all aspects of business operation, in the business policy, and concrete business activities, which over time become commercial practices.

One of the requirements which UCPD sets as necessary for the qualification of non-compliance with one or more commitments contained in the code of conduct as misleading commercial practice concerns the nature of breached commitments, which must be firm and verifiable. This issue is entirely 
fact-specific and based on the circumstances of each particular case. There is no doubt that certain formulations such as "the company will strive to operate socially responsible", or "the company will invest its best efforts for the achievement of the concept of corporate sustainability" do not meet this requirement. The companies sometimes consciously formulate commitments in the code in a very indefinite way to avoid the possibility of application of the legal sanction in case of breach of some of the commitments. Rühmkorf asserts certain provisions contained in the Ethical Trading Initiative Code of Conduct as examples of the provisions which meet this requirement [46] (pp. 136-137). So the provisions of the code which prohibits forced labor, child labor, as well as the provision which proclaims the right of employees to be organized, present firm and verifiable provisions [46] (pp. 136-137).

The third condition for the application of the prohibition of unfair commercial practice on the breaches of codes of conduct which contain the principles of corporate sustainability and CSR requires that the trader indicates to the code in his commercial practice. Indication to the code of conduct may be made in different ways: at the web site, in the brochures, with the special label which points to the access to the code of certain institutions, etc. In this case, it may also be doubtful whether this indication presents a part of the trader's commercial practice, precisely whether it is directly connected to the promotion, sale or delivery of the products. Everything stated about the fulfillment of this condition in the preceding part of the paper when we analyzed the general clause of unfair commercial practice applies here as well. Rühmkorf shares a very similar opinion, arguing that there are many different situations in which exist direct connection between the indication to the code of conduct and the promotion or sale of products (for instance, when the information on accession to the CSR code is placed at the web site close enough to the online shopping facilities) [46] (p. 135).

The last condition requires that breach of the provision contained in the code of conduct has the economic effect on the average consumer, which entails that the average consumer makes or is likely to make a transactional decision that he would not have taken otherwise.

In the end, it is useful to stress that there are two situations prescribed in the blacklist of the unfair commercial practices, relevant for the codes of conduct. These situations are: (1) claiming to be a signatory to a code of conduct when the trader is not, (2) claiming that a code of conduct has an endorsement from a public or other body which it does not have (UCPD, Annex I). The characteristic of both situations is the non-existence of the breaches of concrete provisions contained in the codes. The first situation, speaking the language of UCPD, concerns the absence of the status of the code owner. The second situation is related to the assignment of greater importance to the code by the trader.

\subsection{Breach of the Principles of Corporate Sustainability and CSR through the Concrete Activities of the Companies}

In this part of the paper, we will deal with concrete activities of the companies on the market which harm the principles of corporate sustainability and CSR, and at the same time present an unfair commercial practice. After the analysis of the different forms of appearance of unfair commercial practices, we drew the conclusion that every unfair commercial practice simultaneously presents as well behavior which contradicts the concepts of corporate sustainability and CSR. The corporate sustainability promotes the maintenance of good relationships will all stakeholders, while consumers present a very important group of stakeholders for many companies. The extent of recognition of consumers' needs by the companies, as well as consumers' satisfaction and dissatisfaction is an indicator of the extent of recognition of the needs and satisfaction of other stakeholders by the companies. From this statement emanates that every form of unfair, fraudulent, misleading, aggressive, dishonest, unconscious behavior of the company on the market which is considered to be an unfair commercial practice represents concurrently behavior that directly contradicts one of the main principles of the concepts of corporate sustainability and CSR. Interconnection between unfair commercial practice and the concepts of corporate sustainability and CSR stems also from a certain weight of the companies' behavior which is necessary for the existence of unfair commercial practice as well as for the existence of socially irresponsible and unsustainable behavior. Therefore, the potential for the application of 
rules on the unfair commercial practice is very strong, and it exists even in the situations in which at the first glance does not seem to be a connection between concrete commercial practice and corporate sustainability and CSR.

In order to find the relationship between the unfair commercial practices and corporate sustainability and CSR, we analyzed the Global Reporting Initiative Standards for sustainability reporting, as the most well-known and widespread reporting standards used by modern companies [47]. These standards concern different fields to which the companies and other organizations exert economic, environmental, and social impact. We analyzed these standards aiming to notice which standards may be relevant for the relationship between the company and the consumers, and the company's business practice. The most obvious and the largest relationship was noticed in standard 417 which deals with marketing and labeling. This standard requires companies to report on the type of information which serves for the company's products and services labeling (information on the sourcing of components of the products or services, the content of the products or services, and particularly about substances that might produce an environmental or social impact). GRI Standard 417 also requires companies to provide information with respect to the incidents of non-compliance with regulations and/or voluntary codes concerning product and service information and labeling, as well as regarding marketing communications, including advertising, promotion, and sponsorship [47]. From this standard follows that the potential for the application of the rules on unfair commercial practice exists in relation to the different claims of the companies about the environmental and social impact of its products and services, which we may divide into the environmental, ethical, and sustainability claims. Contrary to the general claim of the company that it operates sustainably and socially responsible, and which concerns the entire business operation of the company, here we talk about the company's claims regarding the concrete products and services. In this type of situation, the application of the rules contained in the "small" general clause of misleading commercial practices is possible. Misleading commercial practices may be performed in two ways: as misleading acts or as misleading omissions.

Before we proceed to the analysis of the possibility to apply the "small" general clause of misleading commercial practices on the company's claims regarding the environmental and social characteristics of its products and services, we will define three basic types of these claims. Environmental claims entail the use of statements which convey the impression that a product does not have a negative impact or have a less harmful impact on the environment than other similar competing products [48] (p. 7). Ethical claims are related to the social component of corporate sustainability, and they convey the message that the manufacturing of the product was conducted according to the generally recognized and accepted standards regarding human rights, employees' rights, working conditions, care about the local community, etc. [48] (p. 7). Sustainability claims are those which emphasize the existence of the manufacturing process whose key focus is on the social and ethical conditions of the production, and on making the smallest possible environmental footprint. Sustainability claims in a way contain elements of both environmental and ethical claims [48] (p. 7).

All these claims may be in different ways subject to sanctions under the provisions on misleading acts and misleading omissions. UCPD recognizes two types of misleading acts: (1) provision of untruthful information, (2) deception (or only a possibility of deception) in any other way, including overall presentation, even if the information is factually correct (UCPD, Art 6(1)). In both cases, there must exist an effect on the transactional decision of the average consumer, and that effect is actual or only possible making transactional decisions that he would not have taken otherwise. The misleading act also must be in relation to one or more exhaustively stated elements from Article 6(1) of UCPD. Among many elements, for our consideration are relevant misleading acts regarding the nature of the product, its benefits, composition, method of manufacture, and specification [41]. Provision of untruthful information as a form of misleading act is perhaps the least significant with regard to the application to the environmental, ethical, and sustainability claims since these claims are very often factually correct but unfair and misleading towards consumers in some other way (claims may be correct but unclear, confusing, ambiguous, they may state information about the characteristics of the 
product or service not materially relevant for its impact on the environment) [42]. For that reason, other forms of misleading acts, as well as misleading omissions, create more important bases for the struggle against unfair claims on the environmental and social characteristics of the products and services.

UCPD recognizes three cases of misleading omissions: (1) when a trader omits material information that the average consumer needs, according to the context, to take an informed transactional decision, (2) when a trader hides or provides in an unclear, unintelligible, ambiguous or untimely manner material information that the average consumer needs to take an informed transactional decision, (3) when a trader fails to identify the commercial intent of the commercial practice if not already apparent from the context (UCPD, Art. 7). Actual or only possible causing the average consumer to make a transactional decision that he would not have taken otherwise is also required consequence in all the cases of misleading omissions. For the subject of this paper, the most relevant are omissions related to the failure to provide material information or the provision of material information in an unclear manner. For example, the company may in its commercial practice invoke the positive effects of its products and services, and hide some other negative effects. It is also a common practice to stand out the environmental and social characteristics of the product as its advantage, while the competing products share same or very similar characteristics [42]. In these cases, we may consider that misleading omission has been established because some of the information necessary for making the transactional decision of the average consumer was not provided to him.

At this place, we should stress out that UCPD deals as well with the issues of the environmental, ethical, and sustainability claims, which are very general, broad, unverifiable, and hard to be documented by evidence. One of the basic requirements for the use of these claims in commercial practice is the possibility to prove their correctness [48]. UCPD indirectly confirms the existence of this requirement, stating that the courts or administrative organs empowered to decide on the existence of unfair commercial practice should have the authority to require the trader to furnish evidence as to the accuracy of factual claims in relation to a commercial practice if, taking into account the legitimate interest of the trader and any other party to the proceedings, such a requirement appears appropriate on the basis of the circumstances of the particular case (UCPD, Art. 12).

The prohibition of misleading commercial practices, as one of the most widespread forms of unfair commercial practices, represents an important indirect mechanism for the achievement and strengthening of corporate sustainability and CSR. This prohibition encompasses numerous behaviors of the companies on the market, by which the companies strive to attract consumers invoking concrete environmental and social characteristics of the products and services. The significance of these provisions for the establishment of corporate sustainability and CSR was recognized in the Guidance for the Implementation of UCPD, which particularly deals with the environmental claims. There are also many other documents that present guides to the companies on how to legally (according to the rules on the prohibition of unfair commercial practice) use environmental, ethical, and sustainability claims. These documents, among which we may distinguish the importance of the Guidance from the Danish Consumer Ombudsman [48], give the rules contained in UCPD analyzed in this part of the paper the function of significant $e x$-ante mechanism which affects companies' behavior in using the claims on the environmental and social characteristics of the products and services.

\subsection{Legal Consequences of Violation of the Prohibition of Unfair Commercial Practices}

The exercise of the function of unfair commercial practices as a significant ex-ante mechanism is based upon the existence of effective, simple and accessible rules that apply in the event of a violation of the prohibition of unfair commercial practices. The unfair commercial practice is not only ex-ante but also ex-post legal mechanism, whereby the exercise of both functions of this institution is interconnected and mutually conditioned. There are two basic ways to protect consumers from unfair commercial practices: individual protection and protection of the collective interests of consumers [32]. 
Individual protection is not subject to EU regulation. Its exercise is based on general legal mechanisms and institutions recognized by the EU Member States. Among these mechanisms and institutions, the civil law rules on the compensation of damages are the most prominent [41]. In many situations, individual protection is not an adequate way of protecting consumers from unfair commercial practices, mostly because the negative impact of those practices on the assets of the individual consumer is often small, insignificant, and as such does not provide sufficient motivation for him to initiate legal proceedings, which can be time-consuming, expensive and complicated.

For the protection of consumers from unfair commercial practices, as well as for the subject of this paper, the protection of the collective interests of consumers is very important, and it can be realized in case of violation of the collective interest of consumers. Almost all cases of violation of the prohibition of unfair commercial practices that were analyzed in this paper infringe the collective interests of consumers. The basic rules for protecting the collective interests of consumers are contained in the Directive on injunctions for the protection of consumers' interests (hereinafter: Injunctions Directive) [49]. This Directive provides the Member States with the freedom to regulate the procedure of protecting the collective interests of consumers as a judicial or administrative procedure. The procedure of protecting the collective interests of consumers cannot be initiated by individual consumers or a group of consumers, but only by "qualified entities", which are bodies or organizations duly established under the law of an EU Member State and which have a legitimate interest in protecting the collective interests of consumers (Injunctions Directive, Art. 3). These bodies or organizations may be subjects of public or private law, and each EU Member State is required to publish a list of bodies or organizations that have the status of qualified entities. Directive envisages two basic measures that the competent court or administrative authority may impose in the case of determining the existence of unfair commercial practices: (1) issuing an order with all due expediency, where appropriate by way of summary procedure, requiring the cessation or prohibition of any infringement, and (2) publication of the decision, in full or in part, in such form as deemed adequate and/or the publication of a corrective statement with a view to eliminating the continuing effects of the infringement (Injunctions Directive, Art. 2(1)). It is noticeable that in the procedure of protecting the collective interests of consumers, the court or administrative body is not authorized to determine the amount of compensation that the company violating the prohibition of unfair commercial practices should pay to the injured consumers or to the state budget. This is considered to be the main deficiency of the current system of protection of the collective interests of consumers in the EU [50]. As the only exception, we may consider a measure of issuing an order for payment of an appropriate amount of money into the state budget to the company that fails to comply with the decision of a court or an administrative body, which has previously established a violation of the institution of unfair commercial practice by that company (Injunctions Directive, Art. 2(1)(c)). However, this exception does not concern the protection of the collective interests of consumers, but it is rather a sanction for failure to comply with a decision of a court or an administrative authority.

At this point, it is important to note that significant EU consumer law reform is underway, as part of the package of actions symbolically named "New Deal for Consumers", which has as a primary objective strengthening the application of consumer law, due to the enormous risk of violation of consumers' rights across the EU. Particularly relevant to the subject of this paper are the proposed changes in the field of protection of collective interests of consumers through the new Directive on representative actions for the protection of the collective interests of consumers, and recently adopted amendments of UCPD, in the part concerning the enforcement of UCPD in the case of unfair commercial practices. The proposal for a new Directive on representative actions for the protection of the collective interests of consumers, which should replace the current Injunctions Directive, introduces the possibility of filing a representative action, by which it may be required not only the cessation and prohibition of the unlawful conduct of a trader but also compensation [51]. New Directive on better enforcement and modernisation of EU consumer protection introduces an obligation for the Member States to provide in their national legislation the private law remedies (compensation, price 
reduction, contract termination) that can be used by consumers affected by the unfair commercial practice [52]. Significant changes also relate to the tightening and more detailed regulation of sanctions for unfair commercial practices, among which there is a provision according to which the severity of the sanction, in some cases characterized by a particularly serious breach of the rules, is linked to the annual turnover of the company responsible for the unfair commercial practice. In other words, it introduces the possibility of imposing a fine in the amount of a certain percentage of the company's annual turnover (Directive on better enforcement and modernisation of EU consumer protection, Article 3).

The possibility to protect the collective interests of consumers through judicial or administrative procedure strengthens the effect of prohibition of unfair commercial practices. Adoption of the analyzed changes from the "New Deal for Consumers" package regarding representative actions would further increase the impact of unfair commercial practices rules on achieving and strengthening corporate sustainability and CSR because these changes facilitate and make more efficient the procedure for the protection of collective interests of consumers. The initiation of a procedure for the protection of the collective interests of consumers has a meaningly negative effect on the reputation and image of the company in the market since this procedure reveals the unfair and dishonest behavior of the company towards consumers. The consequence of this procedure is, in addition to the obligation to act in accordance with the measures imposed by the competent authority, also an indirect detrimental effect that arises from the very initiation of the procedure. This detrimental effect is manifested through a significant deterioration of the company's position in the market, due to consumer dissatisfaction followed by the so-called negative ethical consumerism. This type of ethical consumerism is further manifested in the boycott of the company, i.e., the moral boycott of its products and services and the conducting of a public media campaign against a company that violates the rules of unfair commercial practices.

\section{Conclusions}

At a time when the need to achieve corporate sustainability in the true sense of that word is increasingly visible, efforts are being made across the various scientific disciplines to contribute to the achievement of this goal which is an important determinant of global sustainable development. The contribution of the law is demonstrated in seeking an answer to the question of whether specific and expedient legal regulation dedicated to this concept is needed and possible, or whether the contribution can be made indirectly, using existing legal mechanisms, which would have a new role and purpose in modern times. The fact that the very concept of corporate sustainability is complicated to define, that it is very broad, and encompasses many different areas, leads us to the conclusion that the legal regulation of corporate sustainability is not expedient, and most probably not possible or at least simple. Therefore, the contribution of law to the achievement and strengthening of corporate sustainability is primarily reflected in finding existing legal mechanisms designed to attain some other goals, which are suitable for an innovative and broader interpretation. This new interpretation should have regard to the principles and rules of corporate sustainability and CSR. One such legal mechanism is unfair commercial practice, whose impact on achievement and strengthening corporate sustainability was the subject of this paper.

There are several reasons why we believe that unfair commercial practices can have a significant role in achievement and strengthening corporate sustainability. First, none of the market actors has the power to contribute to the achievement of corporate sustainability independently. In order to achieve this goal, the synergy of all market actors is required. The rules on unfair commercial practices provide a good basis for the common, unified action of different market actors since its suppression is in the interest of consumers, competitors, market and state. Second, the role and importance of consumers and consumer law in the struggle to achieve and strengthen corporate sustainability are not sufficiently recognized, even though consumers present a very powerful means of pressure on companies, as the largest stakeholder group. Third, reducing unfair commercial practices directly 
contributes to enhancing corporate sustainability, because it has a positive effect on the quality of a company's relationship with consumers and other stakeholders, which is one of the basic principles of corporate sustainability and CSR. Fourth, the linkage between sustainable and socially responsible activities of companies with marketing clearly fits into one of the basic objectives of the UCPD, which is to protect consumers from unfair and dishonest advertising in the broadest sense. Fifth, the procedure of protecting the collective interests of consumers, as the most significant form of consumer protection against unfair commercial practices, represents a particular threat to companies, their reputation and position on the market.

The current regulation of unfair commercial practices in the EU consumer law can provide a good basis for achieving corporate sustainability goals. This regulation encourages companies to make true, accurate and precise general claims about their sustainable and socially responsible business operation, as well as to make true and accurate specific, concrete claims about the environmental and social characteristics of their products and services, and to comply with the commitments made in the codes of conduct that incorporate the principles of corporate sustainability and CSR. Otherwise, there is a real possibility of sanctioning companies based on the application of consumer protection rules against unfair commercial practices. Whether this possibility will also become a reality depends primarily on consumers, who by their initiative should encourage consumer organizations and other "qualified entities", empowered to initiate a procedure of protecting the collective interest of consumers, to actually initiate this procedure. The initiation of a procedure itself already has a negative impact on the company's reputation, so it can be expected that companies will try from the very beginning to resolve the dispute amicably and take the path of corporate sustainability, which would also reduce the adverse effects on their reputation. Naturally, courts have an important role as well, and they should be prepared for the implementation of rules on unfair commercial practices in some new situations. Their job could be facilitated by a European legislator, possibly by prescribing some new situations on the blacklist of unfair commercial practices that relate to environmental, ethical and sustainability claims, since this would make the effect of unfair commercial practices on corporate sustainability direct rather than indirect. The attention paid to environmental claims in the Guidance on Implementation of UCPD indicates that it may not be unrealistic to expect a blacklist to be expanded in this regard. However, even without such an extension, an analysis of the general clause and the "small" general clause of misleading commercial practices showed that it is still possible to apply these clauses to inadequate environmental, ethical and sustainability claims, as well as to the breaches of codes conduct of the companies containing the principles of corporate sustainability and CSR.

Finally, it should be emphasized once again that necessary prerequisite for the reduction of unfair commercial practices, which positively influences the achievement and strengthening of corporate sustainability and CSR, is increasing the level of consumers' information and education because only a well informed and educated consumer can contribute to the achievement of the objectives of the legal regulation of unfair commercial practice and corporate sustainability.

Funding: This research received no external funding.

Conflicts of Interest: The author declares no conflict of interest.

\section{References}

1. Sjåfjell, B. Achieving Corporate Sustainability: What is the role of the shareholder? Univ. Oslo Fac. Law Leg. Stud. Res. Pap. Ser. 2016, 10, 377-404.

2. Zhao, J. Promoting more socially responsible corporations through a corporate law regulatory framework. Leg. Stud. 2017, 37, 103-136. [CrossRef]

3. Van Marrewijk, M. Concepts and Definitions of CSR and Corporate Sustainability: Between Agency and Communion. J. Bus. Ethics 2003, 44, 95-105. [CrossRef] 
4. Directive 2005/29/ec of the European Parliament and of the Council of 11 May 2005 Concerning Unfair Business-to-Consumer Commercial Practices in the Internal Market and Amending Council Directive 84/450/EEC, Directives 97/7/EC, 98/27/EC and 2002/65/EC of the European Parliament and of the Council and Regulation (EC) No 2006/2004 of the European Parliament and of the Council, Official Journal of the European Union, L 149/22. Available online: https:/eur-lex.europa.eu/legal-content/EN/TXT/HTML/?uri=CELEX: 32005L0029\&from=EN (accessed on 14 September 2019).

5. Paavola, J. Towards Sustainable Consumption: Economics and Ethical Concerns for the Environment in Consumer Choices. Rev. Soc. Econ. 2001, 59, 227-248. [CrossRef]

6. Stevens, C. Linking sustainable consumption and production: The government role. Nat. Resour. Forum 2010, 34, 16-23. [CrossRef]

7. Wilhelmsson, T. Consumer Law and the Environment: From Consumer to Citizen. J. Consum. Policy 1998, 21, 45-70. [CrossRef]

8. Communication from the Commission to the European Parliament, the Council, the European Economic and Social Committee and the Committee of the Regions: A Renewed EU strategy 2011-14 for Corporate Social Responsibility, /*COM/2011/0681 Final *. Available online: https://eur-lex.europa.eu/legal-content/EN/TXT/ HTML/?uri=CELEX:52011DC0681\&from=EN (accessed on 17 September 2019).

9. Wood, J.D. Measuring Corporate Social Performance: A Review. Int. J. Manag. Rev. 2010, 12, 50-84. [CrossRef]

10. Matten, D.; Crane, A. Corporate Citizenship: Toward an Extended Theoretical Conceptualization. Acad. Manag. Rev. 2005, 30, 166-179. [CrossRef]

11. Gelter, M. Taming or Protecting the Modern Corporation? Shareholder-Stakeholder Debates in Comparative Light. ECGI Work. Pap. Ser. Law 2010, 165, 1-94.

12. Bruno, S. Directors' Versus Shareholders' Primacy in U.S. Corporations Through the Eyes of History: Is Directors' Power "Inherent"? Eur. Co. Financ. Law Rev. 2012, 9, 421-445. [CrossRef]

13. Paul Lee, M.D. A review of the theories of corporate social responsibility: Its evolutionary path and the road ahead. Int. J. Manag. Rev. 2008, 10, 53-73.

14. Henning Richter, U.; Dow, K.E. Stakeholder theory: A deliberative perspective. Bus. Ethics Eur. Rev. 2017, 26, 428-442. [CrossRef]

15. Vinten, G. Shareholder versus Stakeholder-Is there a Governance Dilemma? Corp. Gov. Int. Rev. 2001, 9, 36-47. [CrossRef]

16. Sharma, S.; Henriques, I. Stakeholder influences on sustainability practices in the Canadian forest products industry. Strateg. Manag. J. 2004, 26, 159-180. [CrossRef]

17. Montiel, I. Corporate Social Responsibility and Corporate Sustainability: Separate Pasts, Common Future. Organ. Environ. 2008, 21, 245-269. [CrossRef]

18. Hahn, T.; Scheermesser, M. Approaches to Corporate Sustainability among German Companies. Corp. Soc. Responsib. Environ. Manag. 2006, 13, 150-165. [CrossRef]

19. Schaltegger, S.; Beckmann, M.; Hansen, E.G. Transdisciplinarity in Corporate Sustainability: Mapping the Field. Bus. Strat. Environ. 2013, 22, 210-229. [CrossRef]

20. Carroll, A. The Pyramid of Corporate Social Responsibility: Toward the Moral Management of Organizational Stakeholders. Bus. Horiz. 1991, 34, 39-48. [CrossRef]

21. McBarnett, D. Corporate Social Responsibility beyond Law, through Law, for Law. Univ. Edinb. Sch. Law Work. Pap. Ser. 2009, 3. [CrossRef]

22. Green Paper-Promoting a European Framework for Corporate Social Responsibility [COM (2001) 366-Not Published in the Official Journal]. Available online: https://eur-lex.europa.eu/legal-content/EN/TXT/HTML/ ?uri=LEGISSUM:n26039\&from=EN (accessed on 28 August 2019).

23. Matten, D.; Moon, J. Pan-European Approach. A Conceptual Framework for Understanding CSR. In CSR across Europe; Jonker, A., Wegner, M., Schmidpeter, R., Eds.; Springer: Berlin, Germany, 2004; pp. 339-360.

24. Hiss, S. From Implicit to Explicit Corporate Social Responsibility: Institutional Change as Fight for Myths. Bus. Ethics Q. 2009, 19, 433-451. [CrossRef]

25. Matten, D.; Moon, J. "Implicir" and "Explicit" CSR: A conceptual framework for a comparative understanding of Corporate Social Responsibility. Acad. Manag. Rev. 2008, 33, 404-424. [CrossRef]

26. Hollerer, M. (Ed.) Corporate Social Responsibility. In Between Creed, Rhetoric Facade, and Disregard; Peter Lang AG: Bern, Switzerland, 2012; pp. 29-65. 
27. De Schutter, O. Corporate Social Responsibility European Style. Eur. Law J. 2008, 14, 203-236. [CrossRef]

28. Kong, Y.; Antwi-Adjei, A.; Bawuah, J. A systematic review of the business case for corporate social responsibility and firm performance. Corp. Soc. Responsib. Environ. Manag. 2019, 26, 1-11. [CrossRef]

29. Laasch, O.; Flores, U. Implementing Profitable CSR: The CSR 2.0 Business Compass. In Responsible Business: How to Manage a CSR Strategy Successfully; Pohl, M., Tolhurst, N., Eds.; Wiley: Hoboken, NJ, USA, 2010; pp. 289-309.

30. Blomgren, A. Does corporate social responsibility influence profit margins? a case study of executive perceptions. Corp. Soc. Responsib. Environ. Manag. 2011, 18, 263-274. [CrossRef]

31. Kuhlman, T.; Farrington, J. What is Sustainability? Sustainability 2010, 2, 3436-3448. [CrossRef]

32. Howells, G.; Micklitz, H.W.; Wilhelmsson, T. European Fair Trading Law: The Unfair Commercial Practices Directive; Ashgate Publishing: Farnham, UK, 2006.

33. Collins, H. Harmonization by Example: European Laws against Unfair Commercial Practices. Mod. Law Rev. 2010, 73, 89-118. [CrossRef]

34. Katuoka, S.; Navickaite-Sakalauskiene, I. Misleading actions vs. misleading ommissions under Unfair Commercial Practices Directive-National approach in context. Int. Comp. Jurisprud. 2016, 2, 18-24. [CrossRef]

35. Durovic, M. European Law on Unfair Commercial Practices and Contract Law; Hart Publishing: Oxford, UK; Portland, OR, USA, 2016.

36. Willet, C. Fairness and Consumer Decision Making under the Unfair Commercial Practices Directive. J. Consum. Policy 2010, 33, 247-273. [CrossRef]

37. Howells, G.; Micklitz, H.W.; Wilhelmsson, T. Towards a better understanding of unfair commercial practices. Int. J. Law Manag. 2009, 51, 69-90. [CrossRef]

38. Williams, J.; Hare, C. Early Experiences of the Enforcement of the Unfair Commercial Practices Directive in Scotland. J. Consum. Policy 2010, 33, 377-401. [CrossRef]

39. Sutton, M. Beetwen a Rock and a Judicial Hard Place: Corporate Social Responsibility and Potential Legal Liability under Kasky vs. Nike. UMKC Law Rev. 2004, 72, 1159-1186.

40. Henning-Bodewig, F. TRIPS and Corporate Social Responsibility: Unethical Equals Unfair Business Practices. In Trips Plus 20; Ullrich, H., Hilty, R.M., Lamping, M., Drexl, J., Eds.; Springer: Berlin/Heidelberg, Germany, 2016; pp. 701-724.

41. Beckers, A. The regulation of market communication and market behavior: Corporate Social Responsibility and the Directives on Unfair Commercial Practices and Unfair Contract Terms. Common Mark. Law Rev. 2017, 54, 475-516.

42. Guidance on the Implementation/Application of Directive 2005/29/ec on Unfair Commercial Practices. Available online: https://eur-lex.europa.eu/legal-content/EN/TXT/HTML/?uri=CELEX:52016SC0163\&from= EN (accessed on 7 October 2019).

43. Bethoux, E.; Didry, C.; Mias, A. What Codes of Conduct Tells Us: Corporate social responsibility and the nature of the multinational corporation. Corp. Gov. Int. Rev. 2007, 15, 77-90. [CrossRef]

44. Beckers, A. Enforcing Corporate Social Responsibility Codes: On Global Self-Regulation and National Private Law; Hart Publishing: Oxford, UK; Portland, OR, USA, 2015.

45. Pavillon, C. The Interplay between the Unfair Commercial Practices Directive and Codes of Conduct. Erasmus Law Rev. 2012, 5, 267-288. [CrossRef]

46. Rühmkorf, A. Corporate Social Responsibility, Private Law, and Global Supply Chains; Edward Edgar Publishing Limited: Cheltenham, UK, 2015.

47. Global Reporting Initiative Standards. Available online: https://www.globalreporting.org/standards/gristandards-download-center/ (accessed on 11 October 2019).

48. Guidance from the Consumer Ombudsman on the Use of Environmental and Ethical Claims, etc., in Marketing, August 2014. Available online: https://www.consumerombudsman.dk/media/49009/vejledningom-miljoemaessige-paastande-engelsk-udgave-2.pdf (accessed on 11 October 2019).

49. Directive 2009/22/EC of the European Parliament and of the Council of 23 April 2009 on Injunctions for the Protection of Consumers' Interests, Official Journal of the European Union, L 110/30. Available online: https://eur-lex.europa.eu/legal-content/EN/TXT/?uri=celex\%3A32009L0022 (accessed on 5 October 2019). 
50. European Commission. Communication from the Commission to the European Parliament, the Council and the European Economic and Social Committee-A New Deal for Consumers. Brussels, 2018, COM (2018) 183 Final. Available online: https://eur-lex.europa.eu/legal-content/EN/TXT/HTML/?uri=CELEX: 52018DC0183\&from =EN1 (accessed on 5 October 2019).

51. Proposal for a Directive of the European Parliament and of the Council on Representative Actions for the Protection of the Collective Interests of Consumers, and Repealing Directive 2009/22/EC. Available online: https:/eur-lex.europa.eu/legal-content/EN/TXT/?uri=COM:2018:184:FIN (accessed on 12 October 2019).

52. Directive (EU) 2019/2161 of the European Parliament and of the Council of 27 November 2019 Amending Council Directive 93/13/EEC and Directives 98/6/EC, 2005/29/EC and 2011/83/EU of the European Parliament and of the Council as Regards the Better Enforcement and Modernisation of Union Consumer Protection Rules. Official Journal of the European Union, L 328/7. Available online: https://eur-lex.europa.eu/legalcontent/EN/TXT/HTML/?uri=CELEX:32019L2161\&from=EN (accessed on 22 December 2019).

(C) 2020 by the author. Licensee MDPI, Basel, Switzerland. This article is an open access article distributed under the terms and conditions of the Creative Commons Attribution (CC BY) license (http://creativecommons.org/licenses/by/4.0/). 